Khorishko_Liliia/Tekhnolohichnyi_aspekt_formuvannia_imidzhu_derzhavy.p df?PHPSESSID=59d2r5eu8fo9b60dv967nalr24

4. Accountability Ranking of 50 Ukrainian Cities Transparency International. 2020. URL: https://transparentcities.in.ua/en/accountability-rating

5. Transparency Ranking of 100 Ukrainian Cities. 2020. URL: https://transparentcities.in.ua/en/transparency-rating

DOI https://doi.org/10.30525/978-9934-26-181-7-19

\title{
ВПЛИВ МОВНОГО ІМІДЖУ НА ФОРМУВАННЯ ПОЛІТИЧНОГО ІМІДЖУ ПОЛІТИКА \\ (НА ПРИКЛАДІ ПРЕЗИДЕНТА США РІЧАРДА НІКСОНА)
}

\author{
Трушевич $\boldsymbol{\Gamma}$. Б. \\ аспірант кафедри політологіі \\ Одеський національний університет імені I. I. Мечникова \\ м. Одеса, Україна
}

Політичний імідж - особливий вид іміджу, що включає загальні політичні та психологічні характеристики, властиві іміджу взагалі, так i особливі ознаки, властиві лише конкретного різновиду політичного іміджу. Говорячи про політичний імідж, фахівці нерідко визначають його як цілеспрямовано сформований та пропагований образ кандидата, партії, громадського чи політичного руху, забуваючи про те, що імідж у політичній сфері існує як феномен масової свідомості незалежно від реалізації (а іноді всупереч) передвиборних технологій.

Політичний імідж (образ політика) складається 3 зовнішнього вигляду, вербальної та невербальної поведінки. Основою вербальної поведінки політика $є$ мова, вміння бути оратором, оголошувати промови та виступати перед публікою, звертатись до виборців, як 3 телеекрана, так і під час зустрічей, дивлячись в очі народу.

Мотивом виступів кожного політика є привернення уваги виборця до своєї політичної фігури (робота на впізнаваність), оголошення своїх цінностей та програми (ознайомлення з цілями та відповідь на питання: «Що я можу зробити та чим допомогти?»), відвернення уваги виборця та зміщення акцентів (робота на «відбілення» репутації або ознайомлення 3 першочерговою інформацією). 
Аналіз змісту мовного іміджу політика загалом змушує припустити таке: основні концепти (влада, народ, реформи, добробут, економіка, криза та інших) і позитивна оцінка майбутнього (у якого - вирішення більшості проблем) виявляються постійними величинами у текстах. Дослідниця Іссерс О.С. зазначає, що модель минулого будується під знаком об'єктивності, оскільки задається необхідністю обговорювати лише факти, що відбулися. Щодо реалізації моделі сьогодення, то тут помітні дві тенденції. Одна полягає в тому, що чинні політики представляють її загалом позитивно. Їхні виступи відрізняються оптимізмом i рясніють інформацією про досягнуті результати та виконані різного роду обіцянки. Інша тенденція простежується в текстах опозиціонерів, які здебільшого обирають критичну, негативну модальність під час опису дійсності [1, с. 187].

Для мовного іміджу політика важливо, які образи двох адресатів (конкурентів-опозиціонерів чи народу) формуються у його текстах.

Будаєв Е. В. пише, що оратором можна і не відбутися, але політик обов'язково повинен мати привабливий мовний імідж у діловому спілкуванні. Важливо постійно стежити, щоб розмова із співрозмовником була змістовною. Разом з тим не слід заволодіти розмовою, як вотчиною, 3 якої маєш право вижити іншого, говорили в давнину, навпаки, слід намагатися, щоб кожен мав свою чергу в розмові, як і в усьому іншому $[2$, c. 222].

Публічні виступи $є$ важливою частиною роботи президентів. В США, наприклад, Білий Дім фактично перетворився на справжню фабрику по виробництву текстів виступів. Прийнято вважати, що щорічно середньостатистичний президент США «наговорює» 2,5 тисячі сторінок тексту.

Аналізуючи виступи Річарда Ніксона, то на початку виборчої кампанії 1952 року він став найяскравішою зіркою американської політики. Республіканська партія з радістю зробила його своїм кандидатом і готувала безспірну перемогу на виборах в листопаді, але варто було Ніксону покинути рідну Каліфорнію, як газета «Нью-Йорк пост» надрукувала про нього вбивчу статтю. Тема номера за 18 вересня свідчила «Ніксон живе невідповідно до своїх достатків, його підтримують деякі багачі». У статті було сказано, що група бізнесменів з Південної Каліфорнії створила спеціальний фонд, щоб підтримати сенатора Ніксона. Історія дуже швидко переросла в скандал і газети кричали про це цілий тиждень. Ніксон став заважати виборчій кампанії Езінхауера $\mathrm{i}$ республіканці все більше схилялися до того, щоб його позбутися. Особиста неприязнь Езінхауера по відношенню до Ніксона тільки підливала масла у вогонь. Насправді в цій статті нічого особливого не було, просто були зроблені деякі невірні висновки. Однак Ніксон вважав 
нападки черговими підступами ліберальної еліти і скористався цією можливістю, щоб зробити контратаку на ЗМІ. Ніксон щиро вірив і повторював це навіть 10 років по тому, що преса вела організовану кампанію по очорнінню його репутації. Скориставшись підтримкою республіканського національного комітету, контролюючого ефір, Річард Ніксон отримав 2 дні для того щоб підготувати промову, яка повинна була врятувати його політичну кар'єру. 23 вересня 58 мільйонів чоловік стали слухати, що він відповість на висунуті на нього звинувачення. «Я переконаний, що краще єдина відповідь на наклеп або ж щирі омани це розповісти правду». Цікаво відзначити, що Річард Ніксон першим відкрив історичне значення телебачення. Протягом усієї кар'єри він піддавався нападкам ЗМІ. Теледебати з Джоном Кеннеді в 1960 році привели його до поразки на виборах. Однак він зміг скористатися телебаченням так, як ніхто інший [3].

Промова про собаку Чекерса відчувалася щиро і душевно. Мало хто усвідомлював, що це був поворотний момент, після якого політику стала визначати не партія, а кандидати від неї. Менш, ніж через півгодини Ніксон перетворив себе на потужну зброю партії. «Ось чому я до вас сьогодні звернувся. Я хотів розповісти, як виглядає ця історія 3 мого боку». Яким чином йому це вдалося? Звернення сенатора Річарда Ніксона у вересні 1952 року бачили мільйони виборців і він одним виступом вирішив кілька завдань. В першу чергу він повинен був спростувати звинувачення про те, що його фінансує таємний фонд. У той же час Ніксон спробував переконати публіку в тому, що для нього головне мораль, патріотизм і американська мрія. «Я впевнений, що всі ви слухали або читали звинувачення про те, що я, сенатор Ніксон, прийняв 18 тисяч доларів від групи своїх прихильників. Чи так це? Дозвольте сказати, що це було б неправильно, я підкреслюю неправильно, а не незаконно. Головне питання полягає в тому, законно це чи ні, питання в тому, як до цього поставитися 3 точки зору моралі». Ніксон швидко перемкнув увагу аудиторії з питань законності до питань моралі. Тим самим він підкреслив, що перебуває на більш високому моральному рівні, ніж його обвинувачі. Цю техніку він відточував протягом усього свого президентського терміну [3].

«Я відповім вам, що якби сенатор Ніксон використав хоча б один долар 3 цих 18 тисяч на особисті потреби - це було б аморально. Я скажу вам, що було б аморально таємно отримувати від когось гроші. I ще я скажу, що якби ті, хто давав мені гроші отримували б заміну якусь вигоду - це було б вкрай аморально». Далі Ніксон спробував знизити значення цієї фінансової історії і підкреслити свою чесність. Найпереконливішим виявився простий життєвий випадок в честь якого надалі і назвали всю цю 
промову. «Я повинен розповісти вам ще дещо. Якщо я цього не зроблю, мене знову почнуть звинувачувати. Нам дійсно дещо подарували після початку кампанії. Один 3 жителів Техасу почув по радіо, що мої діти хотіли б завести собаку. Хочете вірте, хочете ні, але за день до того, як ми почали кампанію із залізничної станції нам повідомили, що прийшла посилка. Ми вирушили на станцію, щоб ії забрати. Вгадайте, що нам прислали. Це було щеня кокер-спаніеля, якого нам прислали з Техасу, він чорний з білими плямами. Моя шестирічна дочка Тріша назвала його «Чекерс». Мої діти, подібно всім дітям на світі люблять собаку, і я хочу заявити своїм ворогам, що як би ви не старалися, собаку ми не віддамо». Це класичний приклад підміни понять. Ніксон підмінив розмову про використання незаконних грошових коштів розповідь про щеня. Невже безсердечні люди вимагатимуть, щоб Ніксон повернув маленького Чекерса. Однак просто дістати симпатії аудиторії розповіддю про Чекерса було недостатньо. Ніксон мав переконати аудиторію в тому, що він проста людина, а не грошовий мішок з яким у людей часто асоціюються республіканці. Він пояснив, що завжди добивався всього сам, намагаючись здійснити американську мрію. Він поставив запитання як кандидат повинен оплачувати витрати виборчої кампанії, якщо держава йому не допомагає. «Перший варіант, кандидат повинен бути багатою людиною, так вийшло, що я не багата людина і власних коштів у мене немає». Він розповів, що дружина його носить не норкову шубу, а відмінне республіканське пальто.

Саме так Ніксон відділив себе від привілейованої еліти і таким чином завдав удар своїм політичним опонентам. Ніксон розповів випадок 3 власного життя, випадок цей підкреслював значення наполегливої праці. Він зобразив себе скромною людиною, яка зуміла досягти політичних успіхів тільки завдяки величезним зусиллям. Він здавався першим живим прикладом здійснення американської мрії. Однак у своїй промові він підняв ще одну дуже важливу тему до якої повертався ще не раз, патріотизм. Це можливо найприкметніша частина його звернення, тут Ніксон зачіпає свої улюблені теми нападки преси, Хicca i патріотичний борг [3].

Таким чином, на прикладі найвідомішого виступу Річарда Ніксона, можна зробити висновок, що від ораторського мистецтва, риторики, модальності, інтонації та вміння виступити в потрібний момент залежить мовний імідж політика, який в свою чергу є одним із важливих складових політичного іміджу. Від того, що буде промовляти політик, як він це буде робити і де, залежить подальше формування його образу і загального політичного іміджу. 


\title{
Література:
}

1. Иссерс О.С. Коммуникативные стратегии и тактики русской речи. М, 2005. $308 \mathrm{c}$.

2. Будаев Э.В. Современная политическая лингвистика. М, 2006. $256 \mathrm{c}$.

3. Richard Nixon's «Checkers'» 1952 URL: https://loveman.sdsu.edu/docs/1952Nixoncheckersspeech.pdf

\section{DOI https://doi.org/10.30525/978-9934-26-181-7-20}

\section{ПРОСУВАННЯ ПОЛІТИЧНИХ МЕСЕДЖІВ В СОЦІАЛЬНИХ МЕРЕЖАХ: ПСИХОЛОГІЧНИЙ АСПЕКТ}

\author{
Шлемкевич Т. В. \\ кандидат політичних наук, \\ старший викладач кафедри журналістики \\ Прикарпатський наиіональний університет імені Василя Стефаника \\ м. Івано-Франківськ, Україна
}

Інтеграція інформаційно-комунікаційних технологій у більшість сфер суспільної діяльності суттєво модифікувала підхід до комунікації, підбору каналів спілкування, сприйняття оцифрованих даних, фідбеку тощо. Зазначене стало передумовою для інтенсивного розвитку соціальних мереж не лише як способу неформальної взаємодії, але й в якості платформи для ретрансляції досягнень діяльності органів публічної влади, а саме державно-управлінських структур та органів місцевого самоврядування. Не нехтують цим інструментом і сучасні політики, так як просування політичних меседжів через соціальні мережі здійснює суттєвий вплив на когнітивні та ціннісні рівні політичної культури. Аналогічне враховують маркетологи, які при дослідженні акаунтів беруть до уваги низку відповідних показників, такі як ретвіти, охоплення аудиторії, соціально-демографічні характеристики, лояльність аудиторії, показники із сегменту загальної аналітики (кількість підписників, відвідування сторінки / сайту). Разом з тим, досліджуються індивідуальні показники залежно від соціальної мережі, в якій політик проявляє свою активність. До прикладу, у Twitter - це кількість відстежуваних та користувачів, які відстежують публічну особу; сума неактивних акаунтів; сповіщень (приватних повідомлень); ретвітів та згадувань автора у інших 